\title{
Applying the Basics to Improve the Collection
}

\author{
Linda M. Teel
}

\section{The Author}

\author{
Linda Teel, East Carolina University, Greenville, North Carolina, USA
}

\begin{abstract}
Purpose -This article serves as a follow-up to an article published in Collection Building (vol. 25, no. 4, pp. 129-133) entitled, Inventory: Catalyst for Collection Development which discussed the direct outcomes of an inventory project as they related to effective collection development in a curriculum materials center. This article discusses significant outcomes of change and improvement in a collection based on the inventory outcomes.

Design / methodology / approach -Featuring a case study of the East Carolina University Joyner Library Teaching Resources Center, application of the shelf analysis data is used to develop a long-range plan for implementing changes and improvements in the collection development process. Outcomes are discussed and explained.

Findings - Through assessment, budgeting and collaborative collection development, successful outcomes were accomplished significantly improving and increasing services and resources for users.

Originality / value - The results of an initial inventory project conducted in the East Carolina University Teaching Resources Center improved the relevancy, accuracy, reliability and circulation of the curriculum collection. Using the data from the initial inventory to conduct further assessments, this case study discusses significant outcomes that were accomplished by implementing long-range strategic planning. This article substantiates that a collection inventory definitely provided the catalyst for instigating major changes in the curriculum collection development of the Joyner Library Teaching Resources Center.
\end{abstract}

Article Type: Case Study

Keywords: inventory, collection management, collection development, curriculum materials centers, collaboration, academic libraries 


\section{$\underline{\text { Introduction }}$}

With the present emphasis on the improvement and accountability of educational performance for teachers and students, the role of the curriculum materials center (CMC) must be expanded to meet the instructional and research needs of students and faculty in educational programs. A collaborative effort between librarians, administrators, students, faculty and educators must exist to address the role change which will require changes and improvements to resources, materials and services in order to meet the challenges of the $21^{\text {st }}$ century (Henderson and Barron, 1992). In January 2003, The Guidelines for Curriculum Materials Centers was revised by the ACRL Standards and Accreditation Committee and approved by the Board of Directors of the Association of College and Research Libraries (ACRL). These guidelines address the essential elements that are to be present in curriculum materials centers within university and college settings (America Library Association, 2005). Achievement of the newly revised guidelines will require change and improvements in services, resources, materials and activities. Curriculum materials centers provide pre- and in-service teachers a wide-range of resources, materials, and services focusing on instruction preparation for classroom instruction and experiences; thus, making the expansion and improvement of services and resources essential in order to meet the educational challenges of the $21^{\text {st }}$ century patrons (Henderson and Barron, 1992). Serious consideration must be given to the application of the approved guidelines. Incorporating data from a collection inventory while applying the basics of assessment, budgeting and collaborative collection development will produce an increase of improved services and resources to meet the important role that curriculum materials centers play in the success of educators and education. The 
Teaching Resources Center (TRC) of Joyner Library at East Carolina University maintains a heavily used collection of print and non-print materials that support the university teacher education program. The collection consist of North Carolina state adopted textbooks for Kindergarten $-12^{\text {th }}$ grade instruction, children's and young adult fiction and nonfiction literature, easy picture books, biographies, reference materials and audiovisual resources. The TRC houses more than 56,000 items which were inventoried for the first time in 2003. The results of the inventory project served as the catalyst to challenge and redefine the emphasis in the collection development of the Teaching Resources Center (Shouse and Teel, 2006). This article will discuss the method in which the TRC of Joyner Library used the results of the initial inventory project to conduct further assessment which led to changes and improvements in the collection that produced significant outcomes to better serve users.

\section{$\underline{\text { Literature Review }}$}

While the literature provides substantial numbers of articles on the topics of assessment, budget planning, and collaborative collection development, literature specific to Curriculum Materials Center (CMC) collections is limited. The collections of these centers include a variety of educational resources, materials and services that provide curriculum and instructional support for pre-service and in-service educators in their development of curricula lesson plans, research and instruction. CMCs and school media centers share similar goals making the literature written for and about school media centers applicable and useful. In terms of inventory and collection development, school media centers have similar goals to those of CMCs. Baird (2004) describes step-by-step procedures for assessing collections using statistical sampling emphasizing the need for 
constant assessment to make informed development decisions. Slote (1997) includes helpful observations about the important and often neglected weeding of collections emphasizing the value of a current collection for users. To assist in the development and writing of a CMC collection development policy, The Association of College and Research Libraries (1993) offers a guide with actual sample policies. Jackson (2005) culminates a wealth of experience and knowledge specific to the North Carolina Standard Course of Study including collection analysis to focus on developing a CMC collection based on the North Carolina school curriculum. The newly approved and developed Guidelines for Curriculum Materials Centers from the American Library Association (2005) in conjunction with Carr's (2001) management guide offer the perfect guidance for focusing attention on collection development based on the outcomes of the inventory. For budget preparation, the Baltimore County Public Schools (2005), Evans (2001), and Schachter (2005) provide valuable planning details for preparing and requesting a realistic library budget. Even though these articles focus mainly on school media budgets, the information is transferable and applicable for CMCs. A considerable amount of literature is available on collaborative collection building; however, Mattessich and Monsey (1992) discuss the importance of collaboration and what makes it work. The content of this article used the literature of monographs and journal articles to research data collection, budget planning methods and collaborative collection development in order to incorporate inventory results into an effective plan to achieve positive outcomes. Using the inventory results as the catalyst for planning, significant outcomes were achieved that resulted in improved and increased services for users. 


\section{Purpose of the project}

Initially an inventory was conducted to assess the age, accuracy, and condition of the collection, as well as to determine problems within the collection by which their resolution would provide patrons with more accurate accessibility to the materials. Once the inventory was completed and corrections were made, the accessibility of the collection was greatly improved; however, the TRC realized that serious collection deficiencies existed that needed addressing to improve the collection. Additional assessment was conducted to establish a baseline of the existing collection in terms of Dewey category breakdown, use, currency and budget in order to develop long-range strategic planning to address the cost and magnitude of improvements to better meet the needs of the users. Upon the completion of further assessment, plans were developed that addressed formal recommendations for the collection. This article discusses the changes and improvements made in the collection that produces positive outcomes for the center proving that an initial inventory of a collection can serve as a catalyst for change.

\section{Applying the Basics: Assessment}

Assessment is an important consideration in evaluating the components of a center's programs and collection to determine specific improvements as well as updates, additional resources and services needed. As stated in Library Collection Assessment through Statistical Sampling, assessment is a planning tool, but it must also be carefully planned, shaped by the mission of the library to ensure that the assessment exercise is effective and provides valid, useful information. Assessment information must be gathered from a number of different viewpoints in order to represent both the external 
measures for users and the internal measures of processes, innovation, and growth. Constant assessment provides the basis of information used to develop careful planning as well as informed decisions (Baird, 2004). It is the initial basic step in the process of improving resources, materials and services.

For this reason, assessment was the first basic application used to examine and study both the external and internal measures of the Teaching Resources Center (TRC) at East Carolina University J. Y. Joyner Library. The TRC serves as the curriculum materials center for the campus and is housed in the main library. Graduating the largest number of teachers in the North Carolina university system, the center serves more than 2,900 students majoring in the education profession, more than 300 education faculty members along with thousands of area educators. Since 2002, enrollment in the College of Education has increased more than 35\% (East Carolina University College of Education, 2007). With continued enrollment growth, the demands to maintain and increase resources and materials are critical and essential in supporting successful academic achievement.

The mission of the TRC is to facilitate teaching and learning initiatives by providing resources and services to educators at all levels (Teaching Resources Center, 2005). In order to provide valuable and useful information to assist in accomplishing the mission, an assessment of the center was needed. Since the TRC collection had never been inventoried, an internal assessment or a collection inventory was necessary to establish a base line of facts regarding the collection. The decision to conduct the inventory was quickly determined; however, the process took a more than 1200 staff hours to complete and analyze. The main objective of the inventory was to measure and evaluate the 
resources in terms of users' needs and to reflect on the services offered to provide access to the resources. Additional objectives included ensuring that the collection was accurately reflected in the library catalog; measuring the collection, age, usage and ratio to users; examining each resource based on age, relevance, currency, and condition; mapping the collection to identify areas of deficiencies; ensuring the correct order and location of materials for precise accessibility; adjusting shelves to minimize overcrowding and book damage; considering more effective ways of presentation and signage to improve accessibility; and incorporating specialist knowledge to formulate a budget for maintaining and developing the collection for future needs of the users. The inventory corrected a majority of collection organizational problems eliminating previous accessibility difficulties due to inconsistencies and inaccuracies in the online catalog, shelving of materials, and signage. Additionally, the inventory accentuated definite strengths and weaknesses in the collection which focused on internal processes that needed to be adjusted and refined. Based on the findings of the collection inventory, evidence showed that there were significant weaknesses in the nonfiction collection with a majority of the nonfiction materials being outdated and inaccurate. Additionally, the lack of notable award-winning children's literature available for check out was noted. The collection inventory provided substantial data that served as a catalyst to instigate the need for change and improvement in the collection and services of the TRC (Shouse and Teel, 2006).

To validate the strengths and weaknesses of the collection and to determine concrete recommendations for improvements, a request was made to contract an external agency to conduct an additional collection and facility assessment. Libraries Services Unlimited, 
an independent collection/facilities consultant group, performed an assessment providing a detailed, written report of the findings, which included specific recommendations regarding resources, materials and services of the center. The agency performed a thorough analysis of requested data prior to the visit(collection shelf lists by copyright dates, circulation reports, etc.); an on-site, three-day visit of the center; interviews with members of the center, students and faculty; a comparison of the collection to other peer libraries; observations based on information access and delivery as defined by Information Power: Building Partnerships for Learning (1998) and Impact Guidelines for Media and Technology Programs (2000) and the alignment of the collection to the North Carolina Standard Course of Study. As previously determined by the in-house inventory, the most significant finding of the assessment was validated using the inventory data and the shelf analysis of the nonfiction collection. An overwhelming percentage of the nonfiction collection was more than 10 years old reflecting a need to up-date the collection in conjunction with aggressively weed the out-of-date materials. A general rule-of-thumb for school media collections is that $80 \%$ of the nonfiction collection should be no older than ten years. Additional recommendations included: strengthen and update the reference collection to reflect the K-12 curricula, increase the current budget to better update and maintain the Teaching Resources Center collection, and rearrange/renovate several areas of the Teaching Resources Center to accommodate anticipated increase of services, collaborative learning and usage (Jackson, 2005).

The observations and recommendations based on the collection and facility assessment provided concrete evidence that serious priorities needed to be established in order to update and maintain the collection to meet the needs of the users. As the data 
collected by the initial collection inventory served as the catalyst for major changes in collection development, the consultant's report further validated a necessity for immediate attention to correct the deficiencies of the collection. With concrete internal and external validation, the need for a long-range plan to improve the collection to meet the needs of users was critical. The report was presented to the executive board of Joyner Library as well as the faculty of the Library requesting support to implement the recommendations of the report. Unanimous support was given and planning began to address the report recommendations.

With the completion of the initial assessments and the support of the administration and faculty, the center began to study the consultant's detailed report to develop short and long-range goals to address the recommendations of the report. Short-term goals included revising the goals of the center to reflect the inclusion of a Birth-12 $2^{\text {th }}$ grade collection, revising the collection development plan to include The Guidelines for Curriculum Materials Centers as revised and reviewed by ACRL Standards and Accreditation Committee and approved by the Board of Directors of the Association of College and Research Libraries (American Library Association, 2005), and implementing an aggressive weeding project. Long-range strategic goals included requesting administration to commit to additional budget allocations annually over a given period of time to update the nonfiction collection, focusing attention on collaborative collection development to strengthen the collection, considering additional staffing to increase services, devising an ongoing collection maintenance plan that incorporated continuous inventory and deselect ion, developing a production area in the center, and renovating the 
center. It was determined that the focus of the long-range goals would be updating the nonfiction collection which was crucial to user success.

\section{Applying the Basics: Budgeting}

Each year, CMCs strive to increase the quality of services and collections while successfully balancing the need with budget and cost. The reality of budgeting is that if a decent budget does not exist, then needed resources cannot be purchased and the collection cannot be maintained (Glick, 1999). The preparation of a budget request is often easier than preparing the defense for it. For this reason, it is extremely important to have factual information to support the requests. The more emphasis place on the preparation of the budget requests along with the reasons for the requested increase, the more likely administration will understand and support the need. Investment in reading, research, needs assessment, data collection, and strategic planning will provide documentation and evidence to support the impact of funding on user achievement, which must be clearly communicated to administration to foster support. Effective budget planning is directly related to success in acquiring budget requests (Baltimore County Public Schools, 2005). Overall, the budgeting process is fairly simple; however, it requires careful thought and analysis. Budgeting and planning must be clearly integrated in order to ensure that funding allocations address strategic planning goals. Budgeting reveals valuable information about the history of a library while it projects and plans for the future (Schachter, 2005). Additionally, funding from federal, state and local grants as well as university endowments are sources for consideration. Such funding can assist in updating a collection; however, these types of funding are usually one-time sources and should not be relied upon for maintenance of the collection. 
After the completion of the inventory assessment of the TRC of East Carolina University Joyner Library, the Center developed a long-range budget plan to effectively address the development of the collection. The consultant's report provided major evidence in support of increased funding to update and further develop the collection with major emphasis being placed on the nonfiction materials. Initially, the task seems daunting and overwhelming; however, in order to meet the needs of users it was vital for supporting the teacher education program and area educators. Prior to the consultant's report, a request was made to fund a new faculty position for an Education Curriculum Librarian. This person would be responsible for the collection development of the curriculum collection, which previously had been shared by three members of the TRC. After presenting concrete evidence showing continuous increase in education enrollment, the position was funded due to the justification for the need of a dedicated professional position to oversee the collection development and maintenance. With the new position approved and hired, the first task was to work collaboratively with other TRC team members to revise and update the TRC collection development policy (CDP) which was last revised in 1980. Using Curriculum Materials Center Collection Development Policy (1993) in conjunction with the Guidelines for Curriculum Materials Centers (2005), the CDP was revised and approved by the administration and library governing board.

With the policy in place, a projected budget was the next step in the planning process. After researching local school media budgets based on student enrollment, reviewing TRC allocations from previous years, projecting education enrollment increases, and analyzing the recommendations reported in the consultant's report, a five-year budget plan was developed to address the serious needs of the TRC curriculum collection 
emphasizing the nonfiction collection as the top priority. The plan determined that more than $\$ 150,000.00$ was needed to update the collection; therefore, the plan requested that a minimum of $\$ 30,000.00$ be allocated annually over a five-year period. To further validate the importance of the plan, it was written as a major library strategic planning goal correlating directly to the university strategic planning and the university's emphasis on teacher education. The need for additional funding based on the evidence was unquestionably desperately needed. After the collection was analyzed to determine the number of titles that would be weeded along with the work flow and availability of staffing, short and long-range departmental goals were developed with criteria for accomplishing the collection recommendations. Once the goals and budget plan were finalized, a presentation was made to the administration and library governing board for consideration. It was supported and accepted unanimously.

Immediately, funds were allocated to initiate a children's award approval plan with additional projected funding to be allocated in the fiscal year 2005-06 to support the updating and development of the current Kindergarten to $12^{\text {th }}$ grade curriculum collection, the addition of a core collection for Birth to Kindergarten materials and the addition of early childhood professional materials. The Education Curriculum Librarian developed criteria to accomplish the short and long-range goals incorporating the projected allocations. With the new allocations, the TRC budget realized more than a $500 \%$ increase in funding the first year. With the significance of such funding came the reality that the collection had been overlooked in previous years, which contributed to the declining state of the materials. In order to prevent the reoccurrence of this situation, it was essential to begin projecting the need for ongoing funding to maintain the collection 
once the problem areas of the collection were addressed. Additionally, an aggressive weeding plan based on the newly revised CDP was developed to examine, review and consider more than 12,000 titles for deselection. In order to serve its users properly, a collection must be up-to-date and changing. Criteria for weeding must not make the job an arduous and disturbing task. Balance, subject coverage and quality must be considered during the weeding process (Slote, 1997). The budget and deselection plan required collaboration with the technical services department of the library due to the great impact that massive ordering and deselection would have on acquisitions, cataloging and processing. An additional part-time temporary faculty position was requested and granted to assist in the aggressive weeding project in order to complete the project within two years. Deselection was essential in providing shelving space for the new titles. Also, the TRC maintained "wish lists" of needed materials in the event that university funds could be quickly encumbered in the event of availability during the budget collapse at the end of the fiscal year. During the fiscal year 2005-06, such funds were available, allocated and encumbered by the TRC. Currently in the third year of the budget plan, more than 8,000 new titles have been added to the collection and more than 5,000 have been weeded from the collection providing the much needed updated materials to meet users' needs and expectations. In conjunction with the increased budget allocations and purchase of new materials, circulation statistics increased significantly because the collection provided users with materials that were more useful and beneficial. Currently, TRC materials account for more than $40 \%$ of the total overall circulation of the entire library. 


\section{Applying the Basics: Collaborative Collection Development}

Collaboration goes beyond cooperation or coordination toward bringing two or more groups together for decision making purposes. In the book, Collaboration: What Makes It Work, the definition of collaboration is given as "a mutually beneficial and welldefined relationship entered into by two or more organizations to achieve common goals" (Mattessich and Monsey, 1992). Considering this definition, the development of the TRC collection provided a golden opportunity for collaboration to achieve the common goal of developing a useful, well-maintained, justified curriculum collection. In developing a collaborative collection development model, several factors were considered. TRC environmental factors were critical in developing the collaborative efforts. The TRC had a history and successful record of previous and ongoing collaborative partnerships within the university campus as well as the educational community making the idea nonthreatening and inviting to participants. Additionally, the development of the TRC collection was viewed as a worthy and needed project by users, faculty and community educators lending it to a favorable climate. Based on the TRC record of a strong commitment to meet users' needs, an ongoing climate of trust, understanding and mutual respect among partners had been developed which reinforced support of the model. Thirdly, the collaborative efforts provided participants with a sense of ownership and influence in decision making while building and growing the collection to meet the needs of users. Communication, a shared purpose, and budgetary resources were contributing factors in the successful accomplishment of the collaborative collection building (Laughlin, 2000). The model of collaborative collection building began with the 
Education Curriculum Librarian's ability to build trust, mutual respect and understanding among potential members of the model. Internal collaboration was strengthened by the administrative support of the project and the additional allocations provided to make the project attainable. Another important internal collaborative partnership was formed with the Technical Services department and the TRC. Online discussions along with regular meetings allowed the two departments to prepare for the impact that such a project would have on acquisitions, cataloging and processing which was crucial to making the model successful and timely. The implementation of an aggressive weeding project incurred major staffing issues for the Technical Services department as well as the TRC making collaborative planning an essential element to successful completion. A third internal collaborative partner involved representatives from each department of the College of Education who served as members of the College of Education Library Advisory Committee. The TRC Head of Services and the Education Curriculum Librarian attended meetings of the committee and communicated via email newsletters soliciting participation from faculty in the collaborative collection development model. The committee understood and supported the model realizing the important role that each member played in developing the collection to meet students' needs. Representatives gathered suggested titles from colleagues based on needs in correlation to coursework, classroom unit development and curriculum standards. Suggested titles were sent directly to the Education Curriculum Librarian for consideration. Once materials were ordered, received and processed, faculty members were notified of the materials availability for check out. In conjunction with the College of Education faculty, eight members of the TRC played a vital role in the collaborative collection development 
model. Each TRC member provided expertise in a special area. Providing daily user reference services, instruction as well as assistance in searching and locating needed materials, TRC members developed firsthand knowledge of the collection which translated into valuable input in determining weaknesses and deficiencies of the collection.

Externally, vendors played an important role in contributing to the collaborative collection development model. Meetings were scheduled with prospective vendors to foster an understanding of the type and quality of materials needed for the collection. Mutual respect developed as vendors realized that the Center had access to an endless audience of users who were valuable in reviewing materials as they integrated them into classroom units. The TRC established a Materials Review Center in which vendors sent new materials at no charge for examination and check out by users producing a win/win situation for both groups. In turn, users provided written reviews of materials as feedback and evaluation for the vendors. After materials circulated for one year as review copies, quality materials were added permanently to the TRC collection. Vendors were pleased to receive reviews documenting the quality and usefulness of their materials.

The most important external members of the collaborative collection development model were users. Many areas of the nonfiction collection were updated and further developed through the collaborative efforts and suggestions of users. The TRC serves a wide-range of users from birth to 90+years old. Users provided direct feedback and valuable suggestions of titles to consider for purchase in order to improve the collection based upon their needs. Base upon their observations and use of the collection, users 
were highly encouraged to suggest titles and subject areas that addressed deficiencies in the collection. Suggestions were made via the TRC email account, web suggestion box, department suggestion book or using a formal written request form. Users immediately realized areas of the collection that were not able to satisfactorily meet their needs and expectations. Additional external collaborative partners included area educators who work daily in area public, private and home schools to educate young people. Their participation in the collaborative model provided suggestions that enhanced and extended resources beyond the Center to the real world of application. It was their contributions that offered real experience, expertise and knowledge in the needs of today's classroom. The assessment of the collection provided the evidence needed to request additional funding. The collaborative collection development model in conjunction with developed goals, strategies and criteria allowed the recommendations of the consultant's report to be addressed in order to improve the collection and meet the users' needs. Within three years, significant outcomes were evident.

\section{$\underline{\text { Outcomes }}$}

The first three years of the strategic plan produced significant outcomes. The initial collection inventory improved the accessibility of the collection for users based on the resolution of incorrect call numbers, collection codes, on-line catalog records, and shelving; however, the most significant outcome was in the improvement of the curriculum nonfiction collection. 


\section{Table I \\ Shelf Analysis of Nonfiction Collection \\ Teaching Resources Center \\ Joyner Library \\ East Carolina University \\ 2005}

\section{Copyright Year}

\begin{tabular}{|c|c|c|c|c|c|c|c|}
\hline Dewey Category & $\begin{array}{c}\text { Pre } \\
1975\end{array}$ & $1976-85$ & 1986-95 & 1996-00 & 2001-05 & Total & $\%$ \\
\hline 000-099 & 3 & 20 & 78 & 26 & 7 & 134 & 0.7 \\
\hline 100-199 & 31 & 50 & 165 & 47 & 20 & 313 & 1.6 \\
\hline 200-299 & 72 & 27 & 129 & 34 & 13 & 275 & 1.4 \\
\hline 300-389 & 277 & 511 & 1,924 & 467 & 181 & 3,360 & 17.4 \\
\hline 390-399 & 656 & 172 & 711 & 138 & 41 & 1,718 & 8.9 \\
\hline $400-499$ & 52 & 111 & 350 & 63 & 35 & 611 & 3.2 \\
\hline $500-599$ & 395 & 372 & 2,076 & 250 & 114 & 3,207 & 16.6 \\
\hline 600-699 & 163 & 171 & 1,150 & 171 & 53 & 1,708 & 8.8 \\
\hline 700-799 & 340 & 142 & 821 & 110 & 50 & 1,463 & 7.6 \\
\hline 800-899 & 523 & 133 & 487 & 105 & 29 & 1,277 & 6.6 \\
\hline 900-919 & 292 & 19 & 270 & 40 & 9 & 630 & 3.3 \\
\hline 920-999 & 471 & 141 & 1,225 & 290 & 122 & 2,249 & 11.6 \\
\hline Biography & 1,009 & 51 & 830 & 77 & 77 & 2,044 & 10.6 \\
\hline Ronnie Barnes & 35 & 18 & 249 & 38 & 28 & 368 & 1.9 \\
\hline Total & 4,319 & 1,938 & 10,465 & 1,856 & 779 & 19,357 & 100 \\
\hline Percentage & 22.3 & 10.0 & 54.1 & 9.6 & 4.0 & 100 & 100 \\
\hline
\end{tabular}

(Jackson, 2005)

The data presented in Table I clearly shows that $22.3 \%$ of the materials in the nonfiction

collection had a copyright date prior to $1975,10 \%$ had a copyright date between 1976-

1985, and 54.1\% had a copyright date between 1986-1995 giving the collection a total of

$86.4 \%$ of titles older than 1995 . In terms of titles, this translates to 16,722 of 19,357 titles that were more than 10 years old. Further comparison of the numbers in Table I indicates that the nonfiction collection had only $13.6 \%$ or 2,635 titles of the 19,357 nonfiction collection with a copyright date more recent than 1995. 


\section{Table II}

\section{Shelf Analysis of Nonfiction Collection Teaching Resources Center Joyner Library \\ East Carolina University 2008}

\section{Copyright Year}

\begin{tabular}{|c|c|c|c|c|c|c|c|c|}
\hline $\begin{array}{l}\text { Dewey } \\
\text { Category }\end{array}$ & $\begin{array}{l}\text { Pre } \\
1975\end{array}$ & 1976-85 & 1986-95 & 1996-00 & 2001-05 & 2006-08 & Total & $\%$ \\
\hline 000-099 & 19 & 44 & 210 & 56 & 62 & 36 & 427 & 2.0 \\
\hline 100-199 & 28 & 52 & 171 & 71 & 76 & 69 & 467 & 2.2 \\
\hline 200-299 & 80 & 21 & 137 & 41 & 71 & 39 & 389 & 1.8 \\
\hline $300-389$ & 42 & 123 & 875 & 558 & 648 & 349 & 2595 & 12.1 \\
\hline 390-399 & 271 & 121 & 707 & 184 & 312 & 136 & 1731 & 8.0 \\
\hline $400-499$ & 10 & 30 & 231 & 86 & 143 & 43 & 543 & 2.5 \\
\hline 500-599 & 28 & 91 & 874 & 452 & 1410 & 809 & 3664 & 17.0 \\
\hline 600-699 & 18 & 36 & 580 & 326 & 815 & 395 & 2170 & 10.1 \\
\hline 700-799 & 31 & 36 & 417 & 177 & 469 & 227 & 1357 & 6.3 \\
\hline $800-899$ & 158 & 113 & 524 & 125 & 212 & 78 & 1210 & 5.6 \\
\hline $900-919$ & 31 & 12 & 214 & 54 & 120 & 72 & 503 & 2.3 \\
\hline 920-999 & 105 & 71 & 922 & 425 & 1133 & 408 & 3064 & 14.2 \\
\hline Biography & 573 & 16 & 942 & 143 & 734 & 399 & 2807 & 13.0 \\
\hline $\begin{array}{l}\text { Ronnie } \\
\text { Barnes }\end{array}$ & 33 & 11 & 282 & 98 & 155 & 36 & 615 & 2.9 \\
\hline Total & 1427 & 777 & 7086 & 2796 & 6360 & 3096 & 21542 & \\
\hline Percentage & 6.6 & 3.6 & 32.9 & 13.0 & 29.5 & 14.4 & & 100 \\
\hline
\end{tabular}

In comparison after three years of increased funding, Table II characterizes the shelf analysis of the nonfiction collection indicating that $6.6 \%$ of the materials in the nonfiction collection had a copyright date prior to $1975,3.6 \%$ had a copyright date between 1976-1985, and 32.9\% had a copyright date between 1986-1995 giving the collection a total of $43.1 \%$ of titles older than 1995 . This data translates to 9,290 of 21,542 titles that were more than 10 years old accounting for a $43.3 \%$ deduction in the older materials over a three-year period. Further comparison of the numbers in Table II 
indicated that the nonfiction collection currently has $56.9 \%$ or 12,252 of the 21,542

nonfiction titles with a copyright date more recent than 1995 .

Table III

\section{Budget Allocations for Teaching Resources Center \\ Curriculum Collection \\ East Carolina University 2004-2008}

\begin{tabular}{|c|c|c|c|c|c|}
\hline Funds & $\begin{array}{c}\text { 2003-04 } \\
\text { (Base) }\end{array}$ & 2004-05 & 2005-06 & 2006-07 & 2007-08 \\
\hline $\begin{array}{l}\text { Curriculum } \\
\text { Materials }\end{array}$ & $\$ 9,665$ & $\$ 9,607$ & $\$ 9,242$ & $\$ 10,235$ & $\$ 59,600$ \\
\hline $\begin{array}{l}\text { Children's } \\
\text { Awards Plan }\end{array}$ & $\begin{array}{r}\text { Not } \\
\text { established }\end{array}$ & $\$ 7,774$ & $\$ 5,620$ & $\$ 9,157$ & $\$ 9,000$ \\
\hline $\begin{array}{l}\text { Langford } \\
\text { Endowment }\end{array}$ & $\begin{array}{l}\text { No funds } \\
\text { allocated }\end{array}$ & $\begin{array}{l}\text { No funds } \\
\text { allocated }\end{array}$ & $\$ 55,000$ & $\$ 30,000$ & $\begin{array}{l}\text { No funds } \\
\text { allocated }\end{array}$ \\
\hline $\begin{array}{l}\text { Ronnie Barnes } \\
\text { Endowment }\end{array}$ & $\begin{array}{c}\text { Funds not } \\
\text { available }\end{array}$ & $\begin{array}{c}\text { Funds not } \\
\text { available }\end{array}$ & $\begin{array}{r}\text { Funds not } \\
\text { available }\end{array}$ & $\$ 6,200$ & $\$ 3,200$ \\
\hline $\begin{array}{l}\text { End-of-Year } \\
\text { Funds }\end{array}$ & NA & NA & $\$ 30,000$ & NA & NA \\
\hline Total for Year & $\$ 9,665$ & $\$ 17,381$ & $\$ 99,862$ & $\$ 55,592$ & $\$ 71,800$ \\
\hline
\end{tabular}

As shown in Table III, the significant outcome of a $43.2 \%$ increase in current materials was the primary result of a strong commitment from administration and significant budget increases. The base allocation for the TRC prior to the inventory and consultant's visit was $\$ 9,665$.

Using \$20.52 as the average cost of children's books, such funding only permitted the center to purchase approximately 451 books annually making it impossible to develop, maintain and update a collection of more than 50,000 items (St. Lifer, 2005).

Considering the TRC base funding in 2003, such allocations allowed for less than $1 \%$ of the total collection to be replaced annually. Although analysis of the consultant's data 
presented a reality that was difficult to accept, it provided the evidence that required immediate action to address the condition of the collection. During 2004-2005, the allocation for the Children's Awards Plan was a welcomed addition of $\$ 7,774$ to the TRC budget. However in order to achieve the consultant's recommendations, the approved plan to update the collection by allocating a minimum of $\$ 30,000.00$ annually over a fiveyear period needed to be implemented. During the 2005-2006 year, special endowment funds in the amount of $\$ 55,000$ were allocated to the TRC. An additional $\$ 30,000$ in funds became available at the end-of-the-year after the collapse of the university budget. These allocations in conjunction with the base and Children's Awards funding provided a budget totaling $\$ 99,862$ for the year. This significant increase in funding provided the means by which a strong, collaborative collection development component began. Again in 2006-2007, endowment funding was allocated to provide a TRC budget of $\$ 55,592$. In the third year (2007-2008) of the five-year plan, funding was allocated from the library budget based on enrollment increase funding making the third-year budget total $\$ 71,800$. With two of the five years remaining to update the collection, a gigantic progress in the strategic plan has been achieved with the anticipation of achieving the goal by 2010 . 


\section{Table IV \\ Analysis of Teaching Resources Center Service Joyner Library \\ East Carolina University \\ 2004-2007}

Fiscal Year

\begin{tabular}{|c|c|c|c|c|c|c|}
\hline Service & $\begin{array}{c}\text { 2003-04 } \\
\text { (Base) }\end{array}$ & 2004-05 & 2005-06 & 2006-07 & $\begin{array}{c}\text { Total } \\
\text { increase }\end{array}$ & $\begin{array}{l}\text { \% Total } \\
\text { increase }\end{array}$ \\
\hline Circulation & 13,365 & 18,665 & 23,204 & 24,898 & 11,533 & 46.3 \\
\hline $\begin{array}{l}\text { Circulation-In } \\
\text { house }\end{array}$ & NA & 4,077 & 6,378 & 9,072 & 4,995 & 55.1 \\
\hline $\begin{array}{l}\text { Number of TRC } \\
\text { staff }\end{array}$ & 2 & 3 & 4 & 4 & 2 & 100 \\
\hline $\begin{array}{l}\text { Number of TRC } \\
\text { faculty }\end{array}$ & 2 & 3 & 4 & 4 & 2 & 100 \\
\hline $\begin{array}{l}\text { Desk Reference } \\
\text { Questions }\end{array}$ & 3,591 & 3,967 & 4,475 & 4,641 & 1,050 & 22.6 \\
\hline $\begin{array}{l}\text { Desk General Info } \\
\text { Questions }\end{array}$ & 2,125 & 1,848 & 1,968 & 2,324 & 199 & 8.6 \\
\hline $\begin{array}{l}\text { Instructional } \\
\text { Classes }\end{array}$ & 11 & 57 & 92 & 120 & 109 & 990.9 \\
\hline $\begin{array}{l}\text { Individual } \\
\text { Consultations }\end{array}$ & 6 & 6 & 15 & 41 & 35 & 583.6 \\
\hline
\end{tabular}

The results in Table IV provide a year-by-year analysis of the increase in services of the

Center. With the improvements and additions to the collection, the use of the center and materials increased substantially. Circulation of materials and resources increased $46.3 \%$ with in-house use up 55.1\%. To address the continuous usage increases, the number of staff and faculty in the Center doubled over a three-year period to include 8 departmental members. The TRC desk experienced a steady increase of $31.2 \%$ in reference and informational questions. The increase in instructional classes and consultations was phenomenal. Beginning with a simple collection inventory that served as a catalyst for 
change, a strategic plan was developed to update a collection that produced significant increases in TRC services.

\section{Conclusion}

The basic application of assessment using the results of a collection inventory and a contracted consultant firm provided evidence to propose an immediate need for change to improve the accessibility, accuracy and quality in the Teaching Resources Center curriculum collection of East Carolina University Joyner Library. Upon analyzing the base budget for the TRC, it was evident that a significant increase in funding and allocations was necessary to address the deficiencies and weaknesses of the collection. A strong administrative commitment and approval of proposed increased funding provided the avenue to develop a collaborative collection development model. Once the collaborative collection development model was established, the collection was strengthened to meet users' needs. A significant increase in usage projected a need for increased services. With increased services, the Center flourished due to the internal and external collaborative partnerships formed to accomplish the improvements and development of the collection. Users projected strong feelings of ownership, familiarity and pride in a collection that now met their needs. Promoting the collection was easy and natural as users were eager to tell others about the resources and materials available in the center because they had first-hand knowledge and experience in developing the collection. With three of the five years completed in the strategic planning, significant outcomes resulted from the application of the basics of assessment, budgeting and collaborative collection development to improve and increase services and resources. To maintain and continue to improve the collection, a long-term budget plan is being 
developed to submit for approval to be implemented at the conclusion of the five-year strategic plan. Additionally, a continuous collection inventory process was implemented. The adopted plan staggered the inventory process over a three-year period which drastically reduced corrections and missing items to less than .5\% of the collection. In conjunction with the continuous inventory plan, titles are reviewed continuously to determine accuracy and currency. Deficiencies and the need for replacements are recognized immediately eliminating a backlog. Upon the completion of the current aggressive deselection plan, a continuous deselection plan has been developed for long-

term use. Allowing a collection inventory to serve as the initial catalyst to instigate major changes and improvements in the curriculum collection development of the Teaching Resources Center at East Carolina Joyner Library produced significant outcomes that continue to have major impacts on users.

\section{References}

American Library Association (2005), "Guidelines for Curriculum Materials Centers", available at: www.ala.org/ala/acrl/acrlstandards/guidelinescurriculum.htm (accessed March 10, 2007).

Association of College and Research Libraries Education and Behavioral Sciences Section (1993), Curriculum Materials Center Collection Development Policy, American Library Association, Chicago, IL, pp. 22-38.

Baird, B. J. (2004), Library Collection Assessment through Statistical Sampling, The Scarecrow Press, Inc., Lanham, MD, p. xi-1.

Baltimore County Public Schools, Office of Library Information Services (2005), Budget Planning Guide for School Media Specialists, Baltimore County Public Schools, Baltimore, MD, p.2.

East Carolina University, College of Education (2007), Annual Report, East Carolina University College of Education, Greenville, NC, p.8. 
Evans, G. E. (2001), “The in's and out's of library budget preparation", The Bottom Line: Managing Library Finance, Vol. 14 No.1, pp. 19-23.

Glick, A. (1999), “How Does Your Library Stack Up?” School Library Journal, Vol. 45 No.9, available from EbscoHost Academic Search Premier (accessed March 30, 2007).

Henderson, M. V. and B. G. Barron (1992), "Expanding roles of the curriculum materials center: challenges for the $21^{\text {st century, }}$, Education, Vol. 113 No.2, available from EbscoHost Academic Search Elite (accessed April 15, 2007).

Jackson, G. G. (2005), Collection and Facility Assessment of the Teaching Resources Center, Joyner Library, East Carolina University, Library Services Unlimited, Swansboro, NC, pp.1-4.

Laughlin, S. (Ed.) (2000), "Library networks in the new millennium: top ten Trends," ASCLA Changing Horizons Series, No. 3, Association of Specialized and Cooperative Library Agencies, Chicago, IL, pp. 80-81.

Mattessich, P. and B. Monsey (1992), Collaboration: What Makes it Work, Amherst Wilder Foundation, St. Paul, MN, p. 7.

St. Lifer, E. (2005), “2005 Book Prices,” School Library Journal, Vol. 51 No.3, p. 11.

Shouse, D. L. and L. Teel (2006), "Inventory: catalyst for collection development," Collection Building, Vol. 25 No.4, pp. 129-133.

Schachter, D. (2005). "How to create a realistic budget", Information Outlook, Vol. 9 No 9, pp. 10-11.

Slote, S. J. (1997), Weeding Library Collections: Library Weeding Methods, $4^{\text {th }}$ ed., Libraries Unlimited, Inc. Englewood, CO, p.6.

Teaching Resources Center, Joyner Library, East Carolina University (2005), "Teaching Resources Center Mission and Goals", available at: www.ecu.edu/cslib/trc/misgoals.cfm (accessed March 20, 2007). 